\title{
Soap-opera as a Couture House: Impact of Fashion Statement on Women Television Viewers
}

\author{
Anuradha Bhattacharjee, Dr. Partha Sarkar \\ Department of Mass Communication, Assam University, Silchar, Assam, India
}

\begin{abstract}
Television culture is pre-dominant in India since the inception of Cable Television. Television is popular among the masses as because the viewers become mesmerized by its feature of visual image. Soapopera as a genre emerged in Television industry as a platform of fashion culture inclusive of costumes, hairstyle, accessories, make-up, and furniture. Since women are the main viewers of Television soap-operas, the researcher conducted the study to find out the Television habits of women and also if the fashion portrayal in the soaps effect the women viewers to follow the same. A survey was done on 60 women respondents of Silchar town, who were selected through cluster sampling. The findings revealed that women viewers regularly watch soap-operas and they follow the fashion aspects portrayed in them. This cultural penetration of fashion among women shows that soap-operas have an impact on women in an effective way.
\end{abstract}

Keywords - couture house, fashion statement, impact, soap-opera, women television viewers

\section{INTRODUCTION}

"For the apparel oft proclaims the man"(Hamlet, Act I, Scene 3, Page 3)

When Shakespeare quoted the said line in his drama, years ago; he, too, emphasised on the aspects of dressing of a person and the perception of people about him. This throws light to the fact that fashion is predominant in the social life of a person not even now; but, it was equally in trend then. According to the Oxford Advanced Learner's Dictionary, fashion is something that people wear or own, something that is new and unusual which is meant to draw attention. Soap-opera in India is a powerful platform that constantly witnesses the flow of fashion. Soaps have become a couture house with the portrayal of the latest trend of costume, home decoration, hair-style, accessories, jewellery, make-up, footwear, even certain style of behaviour. Fashion is an inseparable part of soap-operas. Women wearing expensive saris, decked from head to toe in gold, holding a thaali containing fruits and flowers; and, praying sincerely for the welfare of their husbands and his family (Visakha Dharba, 2012). The female characters are perfectly portrayed in regard to their get up from head to toe; right from their clothing to hair-styles, shoes, jewellery, accessories, make-up, even, personified portrayal of independent behaviourFashion factor of soap-opera is largely analysed, now a days. Beautification and enrichment of the casts of soap-operas is given adherence to display them as perfect miniatures of fashion embodiment. Bucks are spent by the producers of the soap-operas on the get up of the casts and the decoration of the set. The so-called homes of the soap-operas look alike the real homes, farther, more beautifully decorated, lavish, and well-maintainedSoap-operas are personified as a couture house where all the female protagonists are traditionally attired, yet, elegant, and graceful. They are neatly maintained with perfection right from their manicured nails with nail-paints and nail-arts to the hair-does. The vamps, even, carry their own style statement in the soaps - they are gorgeously, overtly dressed with bold make-ups; mainly dressed in black, which is in itself the colour of style personification. They wear high heels, stylish dresses, halter-neck and sleeveless blouses, big earrings, heavy eye-does and red lipsticks. Protagonists or the vamps; both, are represented with specific characteristic symbols. Akshara of Yeh Rishta Kya Kehlaata Hai, star plus, is the most popular among the college goers and women for her anarkali salwar suits of chiffon and santoon fabrics, palazzo suits, and designer saris with closed neck blouses. She is fashionable, yet, feminine; and, her fashion statement is a chase among the women. Even, the 'shaadi-ka-joda' that she wore during her marriage with Naitik, is a hit among the real brides. Ishita's permed hair or Gopi bahu's bun, be it a naagin's (Shivanya's) puffed hair-style or lehenga-choli in which she performs her naagin dance; all of them are trend-setters among the women, in their own right. Meera's vulnerable frocks with jackets or her glamorous clad of the six yard sari with a kamar-band accompanied with open curled hair is, in vogue, among young damsels.

\section{SOAP-OPERAS IN INDIA AND THE IMPACT FACTOR}

Indian television has emerged as a powerful means of communication with a phenomenal growth in its credibility. The Indian television has gained widespread popularity in regard to education and entertainment, both. Television began its journey in India in 1959, and with the launch of the SITE in India, the separation of 
radio and television in 1976, and 'the switch of television to colour transmission in 1982', television generated prolific popularity among the masses. After the liberalisation of the broadcast industry and the launch of private channels in the 1990s, Indian television scenario changed abruptly. Successful soap-operas like Hum log, represented a crucial turning point in the rise of television in India, pointing it towards commercialization and consumerism (Aggarwal, p.208). Hum Log was India's first soap-opera which dealt with pro-social issues like family planning. Later, other serials, like, Buniyaad, Khandaan, Shanti; mythological serials - Ramayana, Mahabharata; religious serials, such as, Jai Hanuman, Shri Krishna, Om Namah Shivay; biographical series The Sword of Tipu Sultan; fantasy serials, like, Shaktimaan attracted a large audience. In the later 90s, Ekta Kapoor landed a milestone in the genre of soap-operas by producing popular Kserials, such as, Kyunki Saas Bhi Kabhi Bahu Thi, Kahaani Ghar Ghar Kii, Kasauti Zindagi Kay, Kutumb, Kahin Toh Hoga. She created the storyline with issues like conspiracies, extramarital affairs, sex, murders with gaudy make-up, designer dresses, high-profile home decorations, designer jewellery, chunky accessories. Till date, women are considered as the loyal viewers of Indian television. The cultural depiction in the soaps has an immense impact on the women television viewers, who, unknowingly, adapt the ideas, fashion in their lives. The wardrobes of women are inspired by the costumes of the characters of the soap-operas. Women adorn themselves with jewelleries, accessories. Even, there is a behaviouralistic implantation on the women women television viewers, where certain behavioural traits of the characters have an impact on the women who view them onscreen.

\section{LITERATURE REVIEW}

George Gerbner developed the Cultivation Theory in 1967, which assumed that 'mass media have subtle effects on audiences, who unknowingly absorb the dominant symbols, images, and messages of media.' $\mathrm{He}$ analysed that constant viewing of glamorous locales, big houses, clothes, electronic gadgets stir the expectation of the masses to get such things for themselves. But, he, also, stated that such messages are not good for the poorer section of the society who cannot afford to have them. Jagriti Pande in her study 'Fashion and Stereotypes in Hindi Soap Operas' (Oct, 2013), wrote that the characters are represented as traditional to the extremity. The lead heroine is represented in soft make-up with too much of accessories and in designer ethnic dresses, whereas, the vamp is represented with louder make-up and in skimpy dresses. The impact of soapoperas on people depends on how the viewers react to the serials and what do they adopt from them. This is what Sonia Dhyani put up in her write-up 'Impact of daily soaps on Indian Women' (Jan 19, 2016). The writer said that soap-operas affect the minds of the women, their dressing sense ant the way they talk and interact with people. Girls are judged either as 'the ideal Indian girl' or as 'vamp' by their get-up and their personality but, not by their character. A survey was conducted among 200 female Inoorero University students in Kenya (2012) by Leonard Lusac to find out the effects of foreign soap operas on university female students' perception of lifestyle. The collected data indicated that soap operas have an impact on students' perception of lifestyle like dressing. The study was conducted to find out if there is any influence of the soap operas on female students' perception about family roles, relations, fashion; and, two models - Agenda Setting and Cultivation was utilised.

Arshad Ali, et.al. in their study 'The Impact of Indian Dramas on Language and Dressing of Females' (April 2, 2014) analysed the impact of Indian soap-operas on the language and fashion of the women of Pakistan. Pakistani women are influenced by Indian culture due to westernization and the penetration of Indian culture. They wear fashionable clothes, full make-up, stylish hair-cuts. The researchers conducted a survey on 100 females of Sehowal village in Sialkot, Pakistan and used cluster sampling to carry out the study. The findings revealed that there is an impact of Indian dramas on social, cultural aspects of Pakistani society and Pakistani women proudly wear saris and sleeveless shirts influenced by Star Plus dressing. These dramas are affecting their language, fashion, food, architecture, social behaviour, daily lifestyle. The 'international culture' of Indian dramas are promoting liberalism and modernism in Pakistani society. Marshita is stuck by the slim figures and make-up of Indian actress. The women of Karachi are addicted to the Indian soap-operas and watch them during peak hours. They love them for their 'grandeur, costumes and larger-than life projection'. Pakistani women are crazy for the jewellery worn by the female protagonists and they look for them in their local markets, as they said to an IANS correspondent (Nov 11, 2010). 'Girls overcrowded Neeta Lulla's designer outlet to buy Drashti Dhami's lehenga in Madhubala' (Page 3 News). Serial images impact the people regarding gender images and they, also, impact women's awareness about their appearance (Rajagopal, 2002). Shashi Kaul and Shradha Sahni (2010) analysed the portrayal of women in television serials. The researchers conducted the study in Jammu on 60 couples, 35-50 years old, who were the regular viewers of television, selected purposively. They observed that there is a stereotypical portrayal of women, where women are projected as 'housewives and glamorous'. Majority of the women respondents agreed that serials have an impact on their minds and they decorate their homes and workplaces as they watch in television serials. According to Visakha Dharba (27 March, 2012), the target audience of Indian television serials are mainly women especially housewives and elder women. The serials project the vamps as modern and fashionable and the protagonist as submissive. Media is regarded as central impact bearer of modern society (Aaliya Ahmed and Malik Zahra 
Khalid, 2012). Soap-operas impact the mindset of women on two aspects - their thinking level and their attitudes, behaviour, clothing, lifestyle. Aaliya Ahmed analysed in her study 'Women and Soap-Operas: Popularity, Portrayal and Perception' (2012) that media is effective and influencing regarding behavioural change in women. Women are also affected by the beauty and glamour associated to the roles of women in soap-operas and they feel 'connected to the soap-operas since they can relate their own personal and business life to the show.' Meenu Anand observed that all the female characters in soap-operas wear expensive dress and jewellery with heavy make-up. The protagonists are traditional, while, the vamps are portrayed as a modern, working woman with short hair and 'plunging neckline.'

\section{RATIONALE OF THE STUDY}

In today's contemporary era, fashion is a quintessential venture of women's world. In the words of Coco Chanel, fashion is not something that exists in dresses only. Fashion is in the sky, in the street, fashion has to do with ideas, the way we live, what is happening. Infact, television has become an effective medium of visual representation of fashion quotient. Women are the loyal viewers of television soap-operas and the present study is to see if the fashion statement portrayed in the soap-operas have any impact on the women; if they decorate themselves and their homes depending on what is presented in the soap-operas and their characters.

\section{OBJECTIVES OF THE STUDY}

- To find out the television viewing habits of women television viewers.

- To study the impact of dressing style of female characters on women television viewers.

- To assess the impact of hair-style, accessories, ornaments worn by female characters on women television viewers.

- To ascertain the impact of portrayal of home decoration women television viewers in decorating their own house.

\section{METHODOLOGY}

The researcher conducted the study by using survey method - both, qualitative and quantitative. The data were collected through a questionnaire among women of Silchar town from 18 to 60years of age. The researcher applied cluster sampling to select the sample of the study.

\section{DATA ANALYSIS AND INTERPRETATION}

The researcher conducted a survey among 60 female respondents to find out if the fashion aspects of soap-operas have any impact on women television viewers. General profile of the survey - It was found that $6.66 \%$ of the respondents belonged to $18-24$ years of age, $13.33 \%$ of them belonged to $25-31$ years of age, $16.66 \%$ were between 32 and 38 years and 39-45 years of age respectively. $21.66 \%$ of them belonged to $46-52$ years of age and $25 \%$ of the women were 53 years old and above; where, 57 out of 60 respondents were Hindus and remaining 3 respondents were from the Muslim community. The respondents were asked to mention about their caste category. It was found that $48.33 \%$ were from general category, $15 \%$ marked them as S.C., $1 \%$ was from S.T., 30\% were O.B.C and 5\% marked themselves as others. Out of 60, 3 women were self-employed, i.e. $5 \%, 37$ women were homemakers i.e. $61.66 \%, 8$ women were service-holders, i.e. $13.33 \%$ and 12 women, i.e. $20 \%$ were students. Among the respondents, $81.66 \%$ of the women had no income of their own. People who earned less than Rs. 5000/- per month is $1.66 \%$ and people who earned Rs. 5000/- to Rs. 10,000/- is 5\%, from more than Rs. $10,000 /-$ but, less than Rs. $20,000 /-$ is $8.33 \%$, and $3.33 \%$ of people earn more than Rs. 20,000/per month. When the respondents were asked about their educational qualification, it was found that 6 out of 60 respondents were masters in different subjects, 25 respondents were graduates, 9 of them were H.S. passed, 8 H.S.L.C., 10 of them were not even H.S.L.C. passed, and 2 respondents marked their qualification as others. 10 women were unmarried, 47 were married, 1 woman was a widow, and 2 divorcees. The mother tongue of $78.33 \%$ of women is Bengali, $18.33 \%$ is Manipuri, and $1.66 \%$ of people speak Hindi and Nepali. All the respondents have Television set at their home. 54 out of 60 women television viewers (90\%) have a single television set at home, whereas, 6 of them have two television sets at home. $88.33 \%$ of them have access to cable television and $11.66 \%$ of them use Tata Sky.

Television viewing habits of women:

Table 1:

\begin{tabular}{|l|l|l|l|l|l|l|l|}
\hline & 1day & 2days & 3days & 4days & 5days & 6days & 7days \\
\hline $\begin{array}{l}\text { How } \\
\text { many } \\
\text { days do } \\
\text { you watch }\end{array}$ & & 1 & & & 2 & & 1 \\
\hline
\end{tabular}




\begin{tabular}{|l|l|l|l|l|l|l|l|}
\hline $\begin{array}{l}\text { Television } \\
\text { in a } \\
\text { week? } 18 \\
-24 \text { years }\end{array}$ & & & & & & & \\
\hline $\begin{array}{l}25-31 \\
\text { years }\end{array}$ & 1 & 3 & 1 & & 1 & & 2 \\
\hline $\begin{array}{l}32-38 \\
\text { years }\end{array}$ & 2 & & & & 5 & 3 & \\
\hline $\begin{array}{l}39-45 \\
\text { years }\end{array}$ & 1 & & & & & 8 & 1 \\
\hline $\begin{array}{l}46-52 \\
\text { years }\end{array}$ & & & & & & 5 & 8 \\
\hline $\begin{array}{l}53 \\
\text { above and }\end{array}$ & & & & & & & 15 \\
\hline Total & 4 & 4 & 1 & 0 & 8 & 16 & 27 \\
\hline Total\% & $6.66 \%$ & $6.66 \%$ & $3.33 \%$ & 0 & $13.33 \%$ & $26.66 \%$ & $45 \%$ \\
\hline
\end{tabular}

The respondents were asked about the number of days they watch Television in a week inorder to know about their Television viewing habits. The respondents were divided into 6 age groups. $6.66 \%$ of them watch Television both, once and twice a week. 3.33\% of them watch 3 days a week. Among the women, $13.33 \%$ of women view Television 5days in a week and, $26.66 \%$ of them watch for 6 days. Majority of the viewers; i.e., $45 \%$ of them watch Television each and everyday.

Table 2:

\begin{tabular}{|c|c|c|c|c|c|}
\hline & $<1$ hour & $1-2$ hours & $\begin{array}{l}\text { More than } 2 \\
\text { hours but } \\
\text { less than } 3 \\
\text { hours }\end{array}$ & $3-4$ hours & $\begin{array}{l}\text { More than } 4 \\
\text { hours }\end{array}$ \\
\hline $\begin{array}{l}\text { How many } \\
\text { hours do } \\
\text { you spend in } \\
\text { watching } \\
\text { Television } \\
\text { (18 - } 24 \\
\text { years) }\end{array}$ & 1 & 1 & 2 & & \\
\hline $\begin{array}{l}25-31 \\
\text { years }\end{array}$ & & & 3 & 4 & 1 \\
\hline $\begin{array}{l}32-38 \\
\text { years }\end{array}$ & 1 & 2 & 3 & 4 & \\
\hline $\begin{array}{l}39-45 \\
\text { years }\end{array}$ & & 2 & & 6 & 2 \\
\hline $\begin{array}{ll}46-52 \\
\text { years }\end{array}$ & & & 5 & 6 & 2 \\
\hline $\begin{array}{ll}53 & \text { and } \\
\text { above } & \\
\end{array}$ & & & 4 & 10 & 1 \\
\hline Total & 2 & 5 & 17 & 30 & 6 \\
\hline Total\% & $3.33 \%$ & $8.33 \%$ & $28.33 \%$ & $50 \%$ & $10 \%$ \\
\hline
\end{tabular}

The respondents were asked about the time spent in watching Television by them. The respondents were categorised in different age groups. 3.33\% of them replied that they watch less than an hour per day, $8.33 \%$ of them watch $1-2$ hours, but, $28.33 \%$ of them watch Television more than 2 hours but, less than 3 hours. $50 \%$ of the respondents watch Television $3-4$ hours daily, whereas, only $10 \%$ of the respondents watch Television more than 4 hours. 
Table3:

\begin{tabular}{|l|l|l|l|l|}
\hline & Morning & Afternoon & Evening & Night \\
\hline $\begin{array}{l}\text { At what time } \\
\text { of the day do } \\
\text { you prefer to } \\
\text { watch } \\
\text { Television? }\end{array}$ & $1.66 \%$ & $6.66 \%$ & $5 \%$ & $86.66 \%$ \\
\hline
\end{tabular}

Only $1.66 \%$ of the respondents prefer to watch Television in the morning, $6.66 \%$ of them watch in the afternoon and $5 \%$ of like to watch Television in the evening. Most of the women; i.e., $86.66 \%$, prefer to watch Television at night.

Table 4:

\begin{tabular}{|l|l|l|}
\hline Programmes on Television & Preference (Frequency) & Percentage \\
\hline News and current affairs & 1 & $1.66 \%$ \\
\hline Music & 7 & $11.66 \%$ \\
\hline Soaps & 47 & $78.33 \%$ \\
\hline Comedy shows & & \\
\hline Reality shows & 3 & $5 \%$ \\
\hline Fashion channels & & \\
\hline Religious channels & & \\
\hline Movies & 2 & $3.33 \%$ \\
\hline Cartoons & & \\
\hline Sports & & \\
\hline
\end{tabular}

When the respondents were asked to mark their most preferred programme telecast over Television, $1.66 \%$ of respondents preferred news and current affairs, $11.66 \%$ preferred to watch music channels most, $78.33 \%$ preferred soaps, $5 \%$ preferred reality shows, $3.33 \%$ preferred to watch movies most. As a matter of fact, majority of the respondents liked to watch soap-operas. And, all of the respondents said 'yes', when they were asked if they watch soap-operas. The women viewers insisted that they like to watch soap-operas because of their real-life presentation. Some of the viewers revealed that they have no interest in the plot of the soapoperas. They are the loyal viewers of the soap-operas because they love the actors, and, are attracted towards the traditional costumes of the female actors, ornaments worn by them, their make-ups, body language and the grand set.

Table5:

\begin{tabular}{|l|l|l|l|l|}
\hline & Hindi & English & Bengali & Others \\
\hline In which & $81.66 \%$ & 0 & $18.33 \%$ & 0 \\
$\begin{array}{l}\text { language do } \\
\text { you prefer to } \\
\text { watch soap- } \\
\text { operas? }\end{array}$ & & & & \\
\hline
\end{tabular}

The respondents were asked to express about the language they preferred to watch Television soap-operas. $81.66 \%$ of them liked to watch Hindi soap-operas; whereas, $18.33 \%$ of women liked Bengali soap-operas. No respondents watch Television soap-operas in English or in other languages.

Table6

\begin{tabular}{|l|l|l|}
\hline \multirow{2}{*}{ Channels } & \multicolumn{2}{l|}{ Which channel do you prefer to watch most? } \\
\cline { 2 - 3 } & Frequency & Percentage \\
\hline Star Plus & 35 & $58.33 \%$ \\
\hline Zee TV & 7 & $11.66 \%$ \\
\hline Life OK & 2 & $3.33 \%$ \\
\hline And TV & 0 & 0 \\
\hline Sahara One & 0 & 0 \\
\hline Sab TV & 0 & 0 \\
\hline Colors & 5 & $8.33 \%$ \\
\hline
\end{tabular}




\begin{tabular}{|l|l|l|}
\hline Zee Bangla & 8 & $13.33 \%$ \\
\hline Colors Bangla & 0 & 0 \\
\hline Star Jalsa & 3 & $5 \%$ \\
\hline Others & 0 & 0 \\
\hline
\end{tabular}

Out of different channels telecasting soap-operas, 58.33\% of the respondents prefer to watch Star Plus, $11.66 \%$ of them watch Zee TV, 3.33\% of them prefer to watch Life OK and, 8,33\% of them like to watch Colors. Among the Bengali Television channels of soap-operas, $13.33 \%$ of them prefer to watch Zee Bangla most and, $5 \%$ of them prefer to watch Star Jalsa.

Table 7:

\begin{tabular}{|l|l|l|}
\hline \multirow{2}{*}{} & \multicolumn{2}{|l|}{$\begin{array}{l}\text { Do you follow the costumes of the female } \\
\text { characters of soap-operas? }\end{array}$} \\
\cline { 2 - 3 } & Frequency & Percentage \\
\hline Strongly follow & 32 & $53.33 \%$ \\
\hline Follow & 6 & $10 \%$ \\
\hline Follow often & 21 & $35 \%$ \\
\hline Follow rarely & 1 & $1.66 \%$ \\
\hline Do not follow & 0 & 0 \\
\hline Cannot say & 0 & 0 \\
\hline
\end{tabular}

When the respondents were asked if they follow the costumes of the female characters when they watch Television soap-operas, 32 respondents $(53.33 \%)$ said that they strongly follow the attire of the female actors, 6 of them (10\%) follow their dresses, 21 respondents $(35 \%)$ often follow; whereas, only one respondent $(1.66 \%)$ follow their dresses, rarely. $71.66 \%$ of the respondents wear the same dresses themselves, but, $28.33 \%$ of them do not wear exactly the same. However, $85 \%$ of the women take ideas from the soap-operas, how to dress themselves and $15 \%$ of them replied in the negative. Jewellery is an essential aspect of a woman's life. 81.66\% of the women wear ornaments flaunted by the women characters of the soap-operas. $18.33 \%$ of the women follow their own fashion statement of jewellery. Half of the respondents style their hair as portrayed in different soap-operas. Decoration of homes is the passion of most of the women. Women love to decorate their homes taking ideas from different sources. The women respondents were asked if they take ideas of furniture arrangement from the set of Television soap-operas, $85 \%$ of the respondents take the ideas from the same, but, $15 \%$ of the respondents do not. $81.66 \%$ of women buy different electronic gadgets of homely use after watching Television soap-operas and $80 \%$ of the respondents buy things of home decorations that are portrayed in the homes of the soaps.

\section{CONCLUSION}

Mass-media with its mass influence towards disseminating thoughts, ideas and certain behavioural pattern among its heterogeneous audience; is a powerful agent to incur revolutionary change among women. Television as a media and its influence on women is often asserted as a pivotal topic to analyse the interdependence of women on media and media on women. Television with its visual ability variable is an effective medium of shaping views and perspectives. 'Medium is the message' (McLuhan). The credibility of the medium is responsible for the functional influence on its viewers. Television soap-operas are mostly viewed by women and women can relate their own lives to the characters of the fiction. In this millennium, fashion has a lot to do in a woman's life. Fashion has entered in our lives as an inseparable organ where no one can be without following a certain way of fashion. Ralph Lauren, an American fashion designer, feels that actually he doesn't design clothes, he designs dream. Infact, television industry is often held responsible for this fashion culture. The present study analysed that the fashion aspects portrayed in the soap-operas of Television has an impact on the women television viewers. Women regularly watch television at home and they are mostly attracted towards soap-operas for their representation of traditional aspects of the society. Soap-operas are remarkable among the women for their vivid portrayal of grand homes, interior designing, stylish costumes, ornaments, lavish lifestyle and beautification of females. The delineation of the fashion facet in the Television soap-operas affects the women, in general, and Indian culture is imbibed among the women in this era of westernisation.

\section{REFERENCES}

[1] Aggarwal, Vir. Bala. \& V.S. Gupta.(2002). Handbook of Jouirnalism and Mass Communication, New Delhi, Concept Publishing Company.

[2] Gupta, R. \& Sanjay Kumar.(2012). Mass Communication and Journalism/ Popular Master Guide UGC Net/Set. New Delhi, Ramesh Publishing House. 
[3] Kumar, K.J.(2009). Mass Communication in India, Mumbai, Jaico Publishing House.

[4] Munshi, S.(2010). Prime Time Soap Operas on Indian Television, New Delhi, Routhledge Publication.

[5] Journal Articles:

[6] Ahmed, A. \& Khalid, M.(2012, June). Construction of Contemporary Women in Soap Operas. Commentaries Global Media Journal, Vol. 3/No.1.

[7] Ahmed, A.(2012, June). Women and Soap-operas: Popularity, Portrayal and Perception. International Journal of Scientific and Research Publications, Volume 2, Issue 6.

[8] Anand, M. Women in Television: Depictions and Distortions. Women Studies and Development Centre, University of Delhi.

[9] Dharba, V.(2012, March). Women's Representation in Indian Television Serials. Theses:

[10] Das, Mita.(2012). Impact of T.V. Serials on Social Attitudes of Women in Silchar Town of Assam(Doctoral Dissertation, Assam University, Silchar). 